\title{
Pembuatan Asesmen Berbasis Kelas Melalui Model Partisipatif pada Guru MIPA SMP di Kota Pontianak
}

\author{
Kurnia Ningsih \\ Pendidikan Biologi, FKIP Universitas Tanjungpura
}

\begin{abstract}
Abstrak
Kegiatan ini bertujuan untuk membuat asesmen berbasis kelas melalui model pelatihan partisipatif, dan dapat meningkatkan profesionalitas guru MIPA SMP di Kota Pontianak. Metode yang digunakan adalah pelatihan dengan model partisipatif. Peserta yang terlibat berjumlah 36 orang guru, yang terdiri dari: 30 orang dari SMP Negeri, 4 orang dari SMP Swasta, dan 2 orang dari MTs. Negeri. Membuat asesmen berbasis kelas sesungguhnya telah dilakukan guru-guru MIPA SMP yang ada di Kota Pontianak, namun masih belum mengungkap aspek kemampuan yang ingin diukur pada kisi-kisi yang dibuat, sehingga akan mempengaruhi rumusan indikator soal yang dirumuskan. Setelah melakukan kegiatan pelatihan dengan menggunakan model partisipatif diperoleh 80,56\% dapat dikategorikan cukup baik dalam membuat asesmen berbasis kelas, sedangkan hanya $19,44 \%$ dalam kategori cukup.Dalam menerapkan model pelatihan partisipatif pada pelaksanaan kegiatan ini, pelatih menggunakan metode diskusi, tanya jawab, dan presentasi. Melalui tiga komponen pelatihan partisipatif yaitu pengetahuan, keterampilan, dan pengembangan dapat meningkatkan kinerja guru dalam proses pembelajaran.
\end{abstract}

Kata kunci: asesmen berbasis kelas, model partisipatif

\section{Pendahuluan}

Guru dikatakan profesional apabila telah melaksanakan tugas utamanya yaitu; mendidik, mengajar, membimbing, mengarahkan, melatih, menilai, dan mengevaluasi peserta didik. Salah satu tugas utama guru adalah menilai peserta didik. Dalam menilai peserta didik. hendaknya guru melakukan secara tepat dan obyektif. Dengan memberikan penilaian, guru akan mengetahui kemajuan peserta didik dalam pencapaian kompetensi yang diinginkan. Keberhasilan pendidikan tentunya tidak terlepas dari kinerja guru dalam merencanakan, melaksanakan, menilai dan mengevaluasi peserta didik.

Berdasarkan

Peraturan Pemerintah Nomor 19 Tahun 2005 pasal 63 bahwa penilaian hasil belajar dilakukan oleh pendidik, satuan pendidikan, dan oleh pemerintah Penilaian hasil belajar yang dilakukan oleh pendidik secara berkesinambungan untuk memantau proses, kemajuan, dan perbaikan hasil dalam bentuk ulangan harian, ulangan tengah semester, ulangan akhir semester, dan ulangan kenaikan kelas. Penilaian yang dilakukan pendidik (guru) digunakan untuk: menilai pencapaian 
kompetensi peserta didik, bahan penyusunan laporan kemajuan hasil belajar, dan memperbaiki proses pembelajaran.

Penilaian hasil belajar oleh pendidik menggunakan berbagai teknik penilaian berupa tes, observasi. penugasan perseorangan atau kelompok dan bentuk lain yang sesuai dengan karakteristik kompetensi dan tingkat perkembangan peserta didik. Teknik tes berupa tes tertulis, tes lisan, dan tes praktik atau kinerja. Teknik observasi atau pengamatan dilakukan selama pembelajaran berlangsung dan atau di luar kegiatan pembelajaran. Teknik penugasan baik perseorangan maupun kelompok dapat berbentuk tugas rumah dan atau proyek. Penilaian berupa tes tertulis, penilaian kinerja atau hasil kerja siswa, penilaian proyek, penilaian diri, pengembangan penilaian portofolio merupakan penilaian (asesmen) berbasis kelas (Hayat, dkk., 2008). Asesmen tersebut selayaknya dilakukan guru sebagai kinerja dalam pencapaian profesionalitas. Tetapi kenyataan dilapangan masih belum maksimal dalam pelaksanaannya.

Berdasarkan hasil workshop PLPG 2011 pada guru IPA, diperoleh masih ada guru yang belum pernah membuat instrumen tes penilaian kinerja sebanyak $40 \%$. Selain itu ditemukan pada kisi-kisi ulangan semester yang dibuat oleh guru, belum adanya kesesuaian antara indikator yang dirumuskan dengan soal yang dibuat sebanyak $45 \%$. Dari hasil perencanaan pelaksanaan pembelajaran yang dibuat oleh guru, pada aspek penilaian (soal evaluasi) masih belum relevan dengan tujuan pembelajaran (indikator) yang telah dirumuskan sebanyak $60 \%$.

Sebagai salah satu contoh yang ditemukan dilapangan (Maret: 2012), tentang kesesuaian indikator dengan soal yang dibuat adalah sebagai berikut:

Indikator tertulis "membedakan gejala alam, kejadian dan kebendaan obyek biotik dan abiotik melalui pengamatan".

Soal yang dibuat: Yang merupakan komponen biotik berikut ini adalah
a. makhluk hidup,
b. benda mati,
c. makhluk bersel satu,
d. multi sel

Apa yang telah dituliskan pada contoh, dapat dicermati bahwa pada indikator menginginkan soal yang dibuat dapat mengukur kemampuan siswa pada tahap membedakan gejala alam melalui kejadian dan kebendaan obyek biotik dan abiotik melalui pengamatan. Dari indikator tersebut, siswa juga diminta untuk melakukan pengamatan. Dalam hal ini menuntut aspek kinerja siswa, bukan aspek kognitif. Tetapi soal yang buat masih pada tahap mengingat tentang komponen biotik, dan mengukur aspek kognitif. Selain itu option (pilihan jawaban) yang dibuat. masih belum homogen, stem (pertanyaan soal) masih menggukan kalimat tidak baku.

Jika ditinjau dari aspek yang diukur dari soal-soal yang dibuat guru masih pada level kognitif ingatan dan pemahaman. Sedangkan tuntutan standar kompetensi lulusan (SKL) yang di dalamnya terdapat 
indikator soal, menginginkan kemampuan kognitif yang diukur sampai pada level aplikasi. analisis. sintesis dan evaluasi.

Apa yang dialami guru seperti yang telah dipaparkan. menunjukkan masih diperlukan bantuan yang diberikan pada guru tentang asesmen di sekolah. Karena pelaksanaan asesmen merupakan salah satu aspek untuk penilaian kinerja guru.

Model pelatihan partisipatif (Participatory Training Model) dipilih sebagai metode pelatihan. karena model ini merupakan pembaharuan atau inovasi dari model pelatihan yang selama ini sudah sering digunakan. Model latihan partisipatif menekankan pada proses pembelajaran, di mana kegiatan belajar dalam pelatihan dibangun atas dasar partisipasi aktif dan keikutsertaan peserta pelatihan dalam semua aspek kegiatan pelatihan. mulai dari kegiatan merencanakan, melaksanakan, sampai pada tahap menilai kegiatan pembelajaran dalam pelatihan (Kamal, 2003)

$$
\text { Pelatihan yang dibangun }
$$
pelatih, pada prinsipnya lebih menekankan pada motivasi dan melibatkan kegiatan peserta. Hubungan antara pelatih dan peserta pelatihan dapat ditunjukkan melalui intensitas peranan pelatih diawal pelatihan cukup berperan besar, tetapi diakhir pelatihan semakin berkurang, sedangkan intensitas peranan peserta diawal cukup kecil, tetapi diakhir menunjukkan intensitas yang cukup besar. Dengan pelatihan partisipatif ini, peserta akan dapat melakukan sendiri dan memahami secara bermakna dari apa yang telah diperolehnya, Hal ini dapat digambarkan pada gambar berikut.

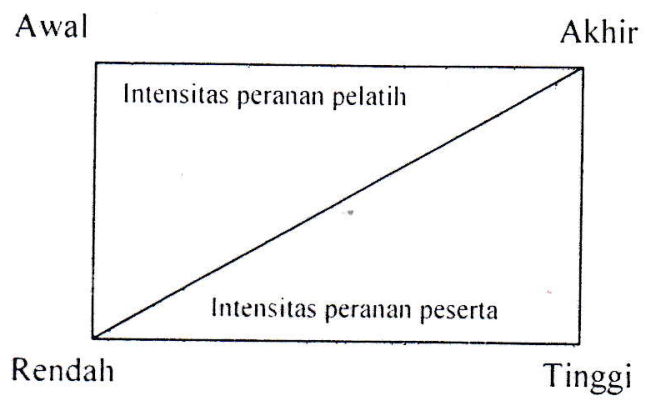

\section{Gambar 1. Hubungan antara Pelatih dan Peserta Pelatihan}

Berdasarkan gambar tersebut, peranan pelatih adalah tinggi; peran ini ditampilkan dalam membantu peserta dengan menyajikan informasi mengenai bahan pelatihan, dan dengan memberikan motivasi dan bimbingan kepada peserta pelatihan. Intensitas kegitan pelatih makin lama makin menurun sehingga perannya lebih diarahkan untuk membantu dan memberikan umpan balik terhadap kegitan pelatihan. Sebaliknya peranan peserta peltihan diawal kegiatan rendah, karena kegiatan awal digunakan hanya untuk menerima bahan pelatihan, informasi, petunjuk, langkah kegiatan. Kemudian partisipasi peserta pelatihan makin lama makin tinggi dan aktif, sehigga diharapkan dapat membangun suasana pelatihan yang lebih bermakna.

Perubahan paradikma pelatihan (training) menjadi belajar (learning) pada peserta pelatihan diharapkan akan membawa dampak terhadap pelaksanaan pelatihan. Menurut Sudjana (2000), pelatihan partisipatif didasarkan pada prinsip; kebutuhan belajar, berorientasi pada tujuan kegiatan belajar, berpusat pada peserta, dan belajar berdasarkan pengalaman. Dari prinsip tersebut tampak adanya keterlibatan peserta 
dalam perencanaan, keikutsertaan dalam perencanaan pelaksanaan, dan keikutsertaan dalam perencanaan evaluasi (Kartika, 2011).

Dari uraian di atas kiranya cukup beralasan jika tim PKM Jurusan PMIPA FKIP Untan ingin membantu dalam memecahkan masalah tentang bagaimana membuat asesmen berbasis kelas melalui model pelatihan partisipatif dalam upaya meningkatkan profesionalitas guru-guru MIPA SMP di Kota Pontianak.

\section{Metode Kegiatan}

Metode yang digunakan dalam kegiatan ini adalah dengan menggunakan metode pelatihan dengan model partisipatif. Guru yang terlibat dalam kegiatan pelatihan pembuatan asesmen berbasis kelas adalah guru-guru SMP yang mengikuti kegiatan MGMP bidang studi MIPA. Peserta yang hadir berjumlah 36 orang yang mewakili 27 sekolah SMP yang ada di Kota Pontianak, dengan rincian 30 orang guru berasal dari SMP Negeri, 2 orang guru mewakili MTs Negeri, dan 4 orang guru mewakili SMP Swasta yang ada di Kota Pontianak. Guru tersebut tergabung pada kelompok Musyawarah Guru Mata Pelajaran (MGMP) Matematika dan Ilmu Pengetahuan Alam (MIPA).

Kegiatan dilakukan di Fakultas Keguruan dan Ilmu Pendidikan Universitan Tanjungpura. Adapun tahap kegitan yang dilakukan adalah:

1. Peserta pelatihan membawa kisikisi dan soal yang pernah dibuat disekolah, baik untuk ulangan harian maupun untuk ujian tengah semester dan ujian semester.

2. Berdasarkan kisi-kisi dan soal yang guru kumpulkan, pelatih mengarahkan - untuk mendiskusikan tentang asesmen berbasis kelas. penyusunan tes, dan pedoman pensekoran.

3. Peserta pelatihan berdidkusi secara berkelompok untuk membahas apa yang telah dipaparkan oleh pelatih.

4. Peserta pelatihan membuat asesmen berbasis kelas, penyusunan tes. dan pedoman pensekoran secara berkelompok.

5. Kelompok yang dibuat adalah; kelopok Matematika, IPABiologi, IPA-Fisika, IPA-Kimia.

6. Setiap kelompok (peserta pelatihan) diberi kesempatan untuk mengukur pemahaman mereka akan materi yang diterima dengan melakukan evaluasi diri.

7. Untuk mengukur keberhasilan pelatihan, hasil pekerjaan kelompok setiap bidang dianalisis dengan menggunakan persentase.

\section{Hasil dan Pembahasan}

Berdasarkan data yang diperoleh dari 36 peserta yang mengikuti kegiatan, dapat dipaparkan sebagai berikut.

Tabel 1. Peserta yang Mengikuti

Kegiatan
\begin{tabular}{|c|c|c|c|}
\hline No. & $\begin{array}{c}\text { Status } \\
\text { Sekolah }\end{array}$ & Jumlah & $\begin{array}{c}\text { Persentase } \\
(\%)\end{array}$ \\
\hline 1. & $\begin{array}{c}\text { SMP } \\
\text { Negeri }\end{array}$ & 30 & 83,33 \\
\hline 2. & $\begin{array}{c}\text { SMP } \\
\text { Swasta }\end{array}$ & 4 & 11,11 \\
\hline 3. & $\begin{array}{c}\text { MTs. } \\
\text { Negeri }\end{array}$ & 2 & 05,56 \\
\hline
\end{tabular}


Sebelum kegiatan pelatihan peserta diminta untuk membawa kisi-kisi dan soal yang pernah dibuat, baik untuk ulangan harian atau tengah dan akhir semester. Dari 36 orang guru, ada 6 orang saja yang membawa contoh kisi-kisi dan soal atau sekitar 16,67\%. Dalam pelaksanaan pelatihan peserta sangat antusias, hal ini dapat digambarkan melalui banyaknya peserta yang ikut terlibat, baik melalui pertanyaanpertanyaan yang disampaikan peserta, maupun dalam bekerja kelompok.

Hasil pekerjaan kelompok dalam kegiatan pembuatan asesmen berbasis kelas, setelah melakukan pelatihan dengan menggunakan model partisipatif diperoleh $80,56 \%$ dapat dikategorikan cukup baik dalam membuat asesmen berbasis kelas, sedangkan hanya 19,44\% dalam kategori cukup.

$$
\text { Dengan }
$$

terlaksananya pelatihan ini memberikan wawasan kepada guru-guru, bagi yang sudah sertifikasi akan tambah meningkat pengetahuannya tentang asesmen berbasis kelas, sedangkan bagi yang belum sertifikasi akan menambah pengetahuan tentang asesmen berbasis kelas. Penggunaan model pelatihan partisipatif dipilih agar peserta terlibat langsung dalam pembuatan asesmen berbasis kelas. Menurut Kartika (2011: 8) ada tiga aspek pokok yang perlu diperhatikan dalam pelatihan yaitu: perolehan pengetahuan. keterampilan, dan pengembangan bakat dalam upaya meningkatkan kinerja seseorang dalam suatu pekerjaan tertentu atau pekerjaan yang spesifik.

Berdasarkan aspek perolehan pengetahuan, melalui pelatihan ini sudah jelas guru memperoleh pengetahuan baru tentang asesmen berbasis kelas. terutama pada aspek pengetahuan yang ingin diukur ketika merumuskan indikator soal. Berdasarkan kisi-kisi yang dibawa peserta sebelum mengikuti pelatihan. perumusan indikator soal belum diikuti dengan aspek pencapaian yang akan diukur atau sering disebut dengan proses kognitif yang diukur seperti; mengingat, memahami, mengaplikasikan, menganalisis, mengevaluasi, dan mencipta (Anderson dan Krathwohl, 2010: 99).

Pada aspek keterampilan, pelatihan dengan model partsipatif mengharapkan pesrta dapat memperoleh keterampilan dengan keterlibatan peserta dalam kelompok. Hal ini berlangsung sesuai dengan apa yang telah direncanakan, semua peserta ikut terlibat aktif dalam kelompoknya ketika membuat asesmen berbasis kelas seperti pada Gambar 2.

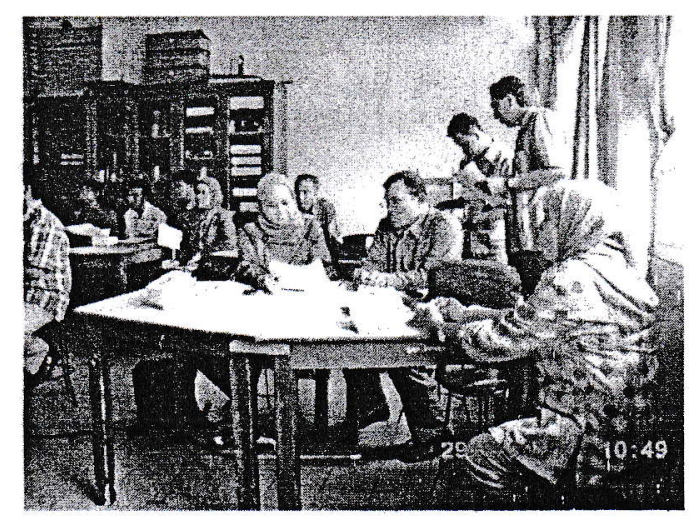

Gambar 2. Kegiatan peserta dalam Kelompok

Pada aspek pengembangan pada pelatihan ini masih belum dilakukan, dan belum menyiapkan instrumennya. Tetapi dengan adanya 
pengetahuan dan keterampilan yang bertambah diharapkan akan mengembangan secara mandiri pembuatan asesmen berbasis kelas ini. sehingga akan dapat mencapai profesionalisme guru SMP yang ada di Kota Pontianak. Menurut Kunandar (2011: 46) guru yang profesional adalah guru yang memiliki kompetensi yang dipersyaratkan untuk melakukan tugas pendidikan dan pengajaran,

\section{Simpulan}

Membuat asesmen berbasis kelas sesungguhnya telah dilakukan guru-guru SMP yang ada Kota Pontianak, namun masih belum mengungkap aspek proses kognitif pada kisi-kisi yang dibuat sehingga akan mempengaruhi rumusan indikator soal. Setelah melakukan kegiatan pelatihan dengan menggunakan model partisipatif diperoleh $\quad 80,56 \%$ dapat dikategorikan cukup baik dalam membuat asesmen berbasis kelas, sedangkan hanya $19,44 \%$ dalam kategori cukup.

Dalam menerapkan model pelatihan partisipatif pada pelaksanaan kegiatan ini, pelatih menggunakan metode diskusi, tanya jawab, dan presentasi. Dengan tiga komponen pelatihan partisipatif yaitu pengetahuan, keterampilan, dan pengembangan, diharapkan dapat meningkatkan kinerja guru dalam proses pendidikan dan pengajaran.

Model pelatihan partisipatif dapat dikembangkan untuk semua jenis pelatihan, terutama dalam pelatihan pendidikan. Tetapi harus tepat memilih metode penyampaian dalam pelatihan.

\section{Daftar Pustaka}

Hayat Bahrul dkk., 2008. Assessment Berbasis Kelas, Jakarta: Pusat Penilaian Pendidikan Badan Penelitian dan Pengembangan Departemen Pendidikan Nasional.

Krathwohl D. R., \& Anderson L. W., 2010. Kerangka Landasan untuk Pembelajaran Pengajaran dan Asesmen Revisi Taksonomi Pendidikan Bloom. Penterjemah: Agung Prihantoro. Yogyakarta:

Pustaka Pelajar.

Kamal Mustofa. 2003. Model-Model

Pelatihan.

Bandung:

Universitas

Pendidikan

Indonesia.

Kartika Ika, 2011. Mengelola Pelatihan Partisipatif. Bandung:Alfabeta

Kunandar. 2011. Guru Profesional Implementasi KTSP dan Sukses dalam Sertifikasi Guru. Jakarta: Rajagrafindo Prasada.

Sudjana, D,. 2000. Metoda dan Teknik Pembelajaran Partisipatif. Bandung:Falah Production 